\title{
The Routledge Handbook of Metaphor and Language
}

\author{
Editors: Elena Semino and Zsófia Demjén
}

\begin{tabular}{|c|c|}
\hline Title & Author \\
\hline Introduction: Metaphor and language & $\begin{array}{l}\text { Zsófia Demjén and } \\
\text { Elena Semino }\end{array}$ \\
\hline \multicolumn{2}{|l|}{ Section 1: Theoretical approaches to metaphor in language } \\
\hline 1. Conceptual metaphor theory & Zoltán Kövecses \\
\hline 2. Figurativeness, conceptual metaphor and blending & Barbara Dancygier \\
\hline 3. Relevance theory and metaphor & Robyn Carston \\
\hline 4. Metaphor, language, and dynamical systems & Raymond W. Gibbs Jr. \\
\hline \multicolumn{2}{|l|}{$\begin{array}{l}\text { Section 2: Methodological approaches to metaphor in } \\
\text { language }\end{array}$} \\
\hline 5. Identifying metaphors in language & Gerard Steen \\
\hline 6. Finding systematic metaphors & Robert Maslen \\
\hline 7. From linguistic to conceptual metaphors & Alice Deignan \\
\hline 8. Corpus-linguistic approaches to metaphor analysis & Heli Tissari \\
\hline $\begin{array}{l}\text { 9. Analysing metaphor in gesture: A set of metaphor } \\
\text { identification guidelines for gesture (MIG-G) }\end{array}$ & Alan Cienki \\
\hline 10. Analysing metaphors in multimodal texts & Elisabeth El Refaie \\
\hline \multicolumn{2}{|l|}{ Section 3: Formal variation of metaphor in language } \\
\hline 11. Metaphor and parts-of-speech & Tina Krennmayr \\
\hline 12. Textual patterning of metaphor & Aletta G. Dorst \\
\hline 13. Genre and metaphor: use and variation across usage events & Rosario Caballero \\
\hline 14. Creative metaphor in literature & Marco Caracciolo \\
\hline 15. Conventional and novel metaphors in language & Gill Philip \\
\hline 16. Metaphor and diachronic variation & Wendy Anderson \\
\hline 17. Metaphor in translation & Christina Schäffner \\
\hline 18. Metaphor in Sign language & $\begin{array}{l}\text { Michiko Kaneko and } \\
\text { Rachel Sutton-Spence }\end{array}$ \\
\hline \multicolumn{2}{|l|}{ Section 4: Functional variation of metaphor in language } \\
\hline $\begin{array}{l}\text { 19. Metaphor use in educational contexts: functions and } \\
\text { variations }\end{array}$ & Jeannette Littlemore \\
\hline $\begin{array}{l}\text { 20. Metaphor and the representation of scientific issues: } \\
\text { climate change in print and online news }\end{array}$ & $\begin{array}{l}\text { Nelya Koteyko and } \\
\text { Dimitrinka Atanasova }\end{array}$ \\
\hline 21. Metaphor and persuasion in politics & Andreas Musolff \\
\hline
\end{tabular}


22. Metaphor and persuasion in commercial advertising

Laura Hidalgo-

Downing and Blanca

Kraljevic-Mujic

23. Metaphor and story-telling

David Ritchie

24. Metaphor, impoliteness, and offence in online

Zsófia Demjén and

communication

Claire Hardaker

\section{Section 5: Applications/Interventions: using metaphor for} problem solving

25. Using metaphor in healthcare: mental health

Dennis Tay

26. Using metaphor in healthcare: physical health

27. Using metaphor as a management tool

Zsófia Demjén and

Elena Semino

28. Using metaphor in the teaching of second/foreign languages

Linda Greve

29. Using metaphor for peace-building, empathy, and reconciliation

Fiona MacArthur

30. Using metaphor to influence public perceptions and policy:

Or, how metaphors can save the world

Lynne Cameron

Section 6: Language, metaphor and cognitive development

31. Metaphor processing

32. Psycholinguistic approaches to metaphor acquisition and use

33. Metaphor acquisition and use in individuals with neurodevelopmental disorders

Joseph Grady

34. Metaphor comprehension and production in a second language

Albert Katz

Gabriella Rundblad

Susan Nacey

Philip Eubanks 